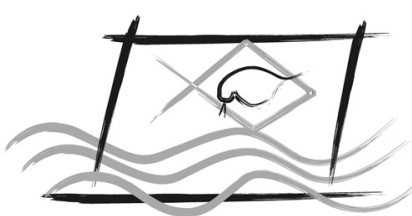

ECOTOX - BRASIL

\title{
DNA damage of erythrocytes of fish Oreochromis niloticus (Perciformes, Cichlidae), after acute exposure to river water receiving effluent from an oil refinery
}

\author{
T.S. Souza ${ }^{1} \&$ C.S. FontanetTi ${ }^{2}$ \\ 'Departamento de Medicina Veterinária, Centro de Ciências Agrárias, Universidade Federal do Espírito Santo, Alegre, Brasil. \\ ²Departamento de Biologia, Instituto de Biociências, Universidade Estadual Paulista, Rio Claro, São Paulo, Brasil.
}

(Received October 30, 2009; Accept August 02, 2010)

\begin{abstract}
The comet assay was applied to erythrocytes of fish Oreochromis niloticus (Perciformes, Cichlidae), exposed in the laboratory to water samples taken from the Paraiba do Sul (Brazil), a river that receives effluents from an oil refinery. Water samples were collected at three points: point 1 - upstream from the discharge of effluent from the oil refinery; point 2 - the dump location of the effluent from the oil refinery, and point 3 - downstream from the oil refinery dump. Artesian well water was used as the control. Samples were collected in May and August of 2004 (dry season) and in November of 2004 and January of 2005 (rainy season). The data obtained indicated the presence of genotoxic substances in points 2 and 3 in all the sampling months. We conclude that the final effluent from the oil refinery, even after treatment, can affect the quality of the Paraíba do Sul River.
\end{abstract}

Keywords: aquatic biomonitoring, comet assay, genotoxicity, Nile tilapia.

Danos no DNA de eritrócitos do peixe Oreochromis niloticus (Perciformes, Cichlidae), após exposição aguda a água de rio que recebe efluente de refinaria de petróleo

\section{Resumo}

O ensaio cometa foi aplicado em eritrócitos do peixe Oreochromis niloticus (Perciformes, Cichlidae), expostos em laboratório à amostras de água oriundas do rio Paraíba do Sul (Brasil), numa área influenciada por uma refinaria de petróleo. As amostras de água foram coletadas em três pontos: ponto 1: montante do despejo do efluente da refinaria de petróleo; ponto 2: local do despejo do efluente da refinaria de petróleo e ponto 3: jusante do despejo da refinaria de petróleo. Água de poço artesiano foi utilizada como controle. As coletas ocorreram nos meses de maio e agosto de 2004 (estação seca) e em novembro de 2004 e janeiro de 2005 (estação chuvosa). Os dados obtidos indicaram a presença de substâncias genotóxicas nos pontos 2 e 3, em todos os meses de coleta. Concluímos que o efluente final da refinaria de petróleo pode afetar a qualidade do rio Paraíba do Sul.

Palavras-chave: biomonitoramento aquático, ensaio cometa, genotoxicidade, tilápia do Nilo. 


\section{INTRODUCTION}

Aquatic ecosystems are the final destination of industrial effluents, whose effects can affect the quality of the waters that receive them. The waste produced by refining crude oil contains many organic and inorganic pollutants, such as phenols, oils and grease, sulphide, nitrogen ammonia and polycyclic aromatic hydrocarbons (Çavas \& Könen, 2008). Although this waste is treated and the contaminants are recovered for re-use by the oil refineries, the final effluent discharged into the water can also contain large amounts of genotoxins (Çavas \& Könen, 2008; Hoshina et al., 2008).

Genotoxicity tests can detect compounds capable of promoting primary damage in the DNA of exposed organisms, and is therefore a warning sign of future environmental problems. The comet assay, under alkaline conditions $(\mathrm{pH}>13)$, detects potentially pre-mutagenic lesions such as breaks in DNA strands, alkaline lysis sites, cross-linking DNA-DNA and DNA-proteins (Singh et al., 1988; Tice, 1995).

Fish have been commonly used as bioindicators of aquatic ecosystems because they play an important role in the food chain, bioaccumulating toxic substances directly and indirectly, through the ingestion of both compounds dissolved in water and previously contaminated organisms (Çavas \& Ergene-Gozukara, 2005; Biagini et al., 2009). The species $O$. niloticus is one of the most commonly used in genotoxicity and mutagenicity tests because it is sensitive to various classes of contaminants (Palhares \& Grisolia, 2002; Souza \& Fontanetti, 2006; Ventura et al., 2008; Hoshina et al., 2008). Recently, the effectiveness of the comet assay in erythrocytes of several species of fish has been proven (Russo et al., 2004; Çavas \& Kopen, 2008; Christofoletti et al., 2009).

Several papers have reported an association between DNA damage and mutagenicity in fish and rivers affected by refinery effluents (Çavas, \& Ergene-Gözükara, 2005; Hoshina et al., 2008) or influenced by the petrochemical complex (Pantaleão et al., 2006; Lemos et al., 2007 and 2008).

The purpose of this study was to detect the presence of genotoxins in the waters of a river receiving effluent from an oil refinery, through the comet assay used in the species $O$. niloticus.

\section{MATERIAL AND METHODS}

\section{Characterization of the study area and collection of water samples}

The Paraíba do Sul is an important Brazilian river, whose basin covers three states in southeastern Brazil: São Paulo (Vale do Paraíba), Rio de Janeiro and Minas Gerais (Zona da Mata Mineira). The São Paulo region of the Paraiba do Sul River is heavily industrialized and urban, with about two hundred industries and 1.5 million people. According to the National Council of the Environment (CONAMA, 2005), the waters of the Paraíba do Sul may be used for the domestic water supply, after conventional treatment, and for the protection of aquatic communities, primary contact recreation (swimming, water-skiing and diving), the irrigation of vegetables and fruit trees, and fish farming and fishing. However, one of the main problems for the Paraiba do Sul is the daily discharge of effluents.

Petroleum refineries require large quantities of water in the refining process, and the effluents produced can contain a great variety of organic and metallic pollutants, including phenol, oils and greases, sulphide, ammonia and polycyclic aromatic hydrocarbons (PAHs) (Braile \& Cavalcanti, 1993). The effluents from oil refinery contain an average of 1281.7 $\mathrm{mg} \mathrm{L} \mathrm{L}^{-1}$ of dissolved solids, $393.40 \mathrm{mg} \mathrm{L}^{-1}$ of organic matter volatile, $899.20 \mathrm{mg} \mathrm{L}^{-1}$ of organic matter fixed, $\mathrm{pH} 7.3,4.97$ $\mathrm{mg} \mathrm{L}^{-1}$ of ammonia, $10.86 \mathrm{mg} \mathrm{L}^{-1}$ of nitrate, $586.81 \mathrm{mg} \mathrm{L}^{-1}$ of chloride, $1.05 \mathrm{mg} \mathrm{L}^{-1}$ of phosphate, $0.028 \mathrm{mg} \mathrm{L}^{-1}$ of phenols, $5.59 \mathrm{mg} \mathrm{L}^{-1}$ of oils and greases, $0.008 \mu \mathrm{L}^{-1}$ of benzene, and 0.03 $\mu \mathrm{L}^{-1}$ of benzo(a)pirene (Convênio Petrobrás-FUNDUNESP, São José dos Campos, 2003). Before disposal in the Paraiba do Sul River, this effluent receives several physical-chemical treatments, such as flotation, flocculation, biodisk and activated sludge treatment.

Water samples were collected from the Paraíba do Sul River in São Jose dos Campos, São Paulo, Brazil (Fig. 1), according to the protocol of the Environmental Sanitation and Technology Company (CETESB, 1987). The samples were collected in May, August and November 2004 and January 2005. Three sampling sites, $500 \mathrm{~m}$ apart, were established. Point 1: upstream from the disposal of effluent from a petroleum refinery; Point 2: the dumping point of the effluent from an oil refinery and Point 3: downstream from the effluent discharge from the oil refinery.

The water samples collected were transported in amber bottles, on ice, to the Department of Biochemistry, University of São Paulo State, UNESP, Rio Claro, São Paulo, Brazil,

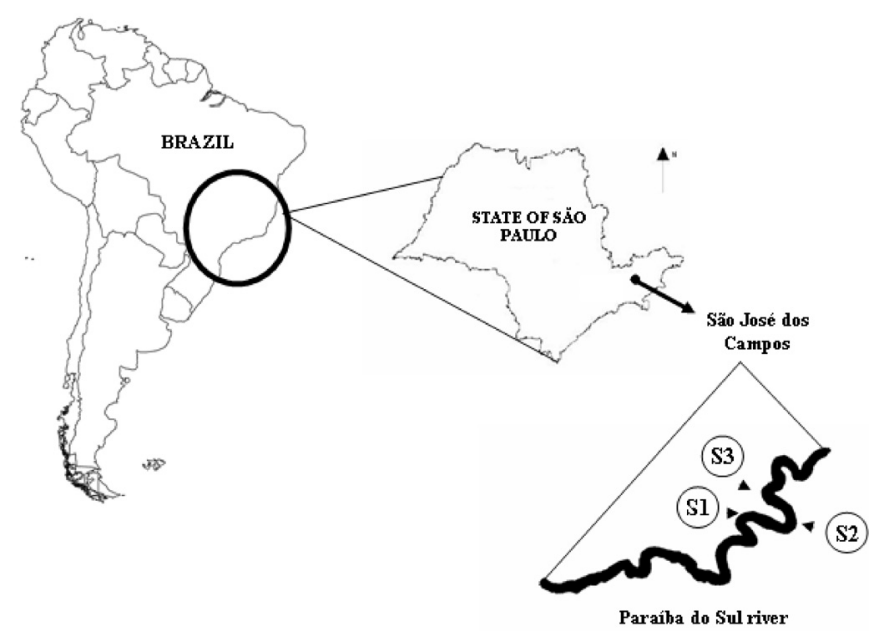

Figure 1. São José dos Campos and collection sites in Paraíba do sul river, in na área affected by na oil shale processing plant. S1: upstream the waste discharge; S2: located at the point where the wastes from the oil shale plant are released; S3: downstream the waste discharge. 
where they remained at $4{ }^{\circ} \mathrm{C}$ until the beginning of the experiment.

\section{Climatological data}

Climatological data from the Surface Meteorological Station at São José dos Campos for the months in which the water samples were collected from the Paraíba do Sul were obtained from the Department of Air Space Control - São Paulo Flight Protection Service, Brazil.

\section{Experimental organisms}

The species O. niloticus (Perciformes, Cichilidae), popularly known as Nile tilapia, was used in this work because it is commercially important in the State of São Paulo, Brazil, being an important source of protein for the population (Tavares-Dias \& Moraes, 2003). We used eighty individuals, with an average length of $15 \mathrm{~cm}$, in order to avoid intraspecific differences related to the size and age of the animals. The specimens, obtained from fish culture (UNESP - São José do Rio Preto, São Paulo, Brazil), were brought to the Water Toxicity Laboratory of the Department of Biochemistry, University of São Paulo State, UNESP, Rio Claro, where they were acclimatized in a tank containing artesian well water in a system with aeration and filtration $(\mathrm{pH} 7.28$; hardness $=16.4$ $\mathrm{mg} \mathrm{L}^{-1}$, chloride $=0.82 \mathrm{mg} \mathrm{L}^{-1}$ ), at an average temperature of $23^{\circ} \mathrm{C}$

\section{Bioassay}

Four tanks were used, each with capacity for $20 \mathrm{~L}$ of water. Of these, three were filled with $12 \mathrm{~L}$ of water collected from the Paraiba do Sul River, as described above, and one tank was filled with $12 \mathrm{~L}$ of water from an artesian well $(\mathrm{pH} 7.28$; hardness $=16.4 \mathrm{mg} \mathrm{L}^{-1}$, chloride $=0.82 \mathrm{mg} \mathrm{L}^{-1}$ ). Five fish were randomly placed in each aquarium, where they remained for $72 \mathrm{~h}$, in accordance with Grisolia \& Cordeiro (2000). The animals were not fed during the experiment.

No positive control was performed. However, in the Cytogenetic and Mutagenesis Laboratory (UNESP, Rio Claro), previous studies showed the sensibility of $O$. niloticus to several chemicals agents and environmental samples (Souza and Fontanetti, 2006; Ventura et al., 2008; Hoshina et al., 2008; Christofoletti et al., 2009). Also, other researchers have reported the sensitivity of this species (Palhares \& Grisolia, 2002 ), including in the detection of genotoxicity from refinery effluents (Çavas \& Ergene-Gözükara, 2005).

\section{Comet assay}

Blood samples from each specimen of $O$. niloticus were obtained by cardiac puncture using heparinized syringes. The comet assay was performed according to Singh et al. (1988), with some modifications. Pre-gelatinized slides containing agarose (normal melting point $1.5 \%$ ) received $10 \mu \mathrm{L}$ of cell suspension $(5 \mu \mathrm{L}$ of blood diluted in $1000 \mu \mathrm{L}$ of fetal bovine serum $)+120 \mu \mathrm{L}$ of low melting point agarose $(0.5 \%)$ at $37^{\circ} \mathrm{C}$. The slides were mounted with a cover slip and kept in a refrigerator for 1 hour in a lysis solution $(1 \mathrm{~mL}$ Triton X-100, $10 \mathrm{~mL}$ of DMSO and $89 \mathrm{~mL}$ of lysis stock solution of $\mathrm{pH}$ 10 - lysis stock solution: $2.5 \mathrm{M} \mathrm{NaCl}, 100 \mathrm{mM}$ EDTA, 10 $\mathrm{mM}$ Tris and $8 \mathrm{~g}$ of solid $\mathrm{NaOH}$ to $1 \mathrm{~L}$ ). After analysis, the cover slips were gently removed and the slides were placed for 20 minutes in an electrophoresis tank containing buffer solution $(300 \mathrm{mM} \mathrm{NaOH}+1 \mathrm{mM}$ EDTA, $\mathrm{pH} \sim 13)$ at $4^{\circ} \mathrm{C}$, to relax the DNA molecules. Electrophoresis was performed in the same solution, with an electrical current of $25 \mathrm{~V}, 300$ $\mathrm{mA}$, for 20 minutes. The slides were then neutralized with buffer $(0.4 \mathrm{M}$ Tris- $\mathrm{HCl}, \mathrm{pH} 7.5)$ for 15 minutes and dried at room temperature, fixed in $100 \%$ ethanol for 10 minutes, and stained with ethidium bromide $\left(0.02 \mathrm{mg} \mathrm{mL}^{-1}\right)$.

The slides were analyzed using a fluorescence microscope equipped with a filter B $-3^{4}$ (excitation: $\mathrm{i}=420-490 \mathrm{nM}$, barrier: $\mathrm{I}=520 \mathrm{nM}$ ) in a $400 \mathrm{x}$ objective lens. One hundred (100) nucleoids were analyzed per fish, totalling 500 nucleoids per treatment. The nucleoids were classified into migration categories according to the size of the comet's tail: grade 0 : no tail, class 1: comet with a short tail, class 2: tail equal to or twice the diameter of the comet head, class 3: tail more than twice the diameter of the comet head (Rigonato et al., 2005). The extent of the damage was expressed as the average percentage of nucleoids with minimal, medium and maximum damage (Çavas \& Könen, 2008). The average damage score was also calculated, that is, the sum of the nucleoids in each category per migration comet multiplied by the same (0-3), so that the scores can range from 0 (all cells without harm 0x100) to 300 (all cells with maximum damage - 3x100).

The analysis of variance (ANOVA) and Dunett's multiple comparison test were applied $(\mathrm{p}<0.01)$.

\section{RESULTS}

The months of May and August of 2004 presented lower maximum and minimum temperatures, relative humidity, rainfall and total number of rainy days than in the months of November of 2004 and January of 2005 (Table 1). The climatological data in São José dos Campos falls within the Cwa type climate (Köppen system), characteristic of the Paraíba Valley in São Paulo, which is dominated by rainy summers (November-January), dry winters (June-September) and average temperatures above $22^{\circ} \mathrm{C}$ in the warmest month and below $18^{\circ} \mathrm{C}$ in the coldest month.

In this study, genotoxic compounds were detected at point 1 only in August 2004 (Table 2).

During both the dry season and the rainy season, the average scores for DNA damage in $O$. niloticus exposed to water from points 2 and 3 were statistically significant $(\mathrm{p}$ $<0.05)$ when compared with the control. In these collection points, there was a predominance of comets in Classes 2 and 3 , with medium and high DNA damage in the erythrocytes of the exposed fish (Table 2). 
Table 1. Climatological data from São José dos Campos city, for the periods of water sample collection from the Paraíba do Sul river.

\begin{tabular}{lcccc}
\hline Climatological data & May/2004 & August/2004 & November/2004 & January/2005 \\
\hline Maximum temperature $\left({ }^{\circ} \mathrm{C}\right)$ & 21.6 & 19.24 & 25.0 & 26.0 \\
Minimum temperature $\left({ }^{\circ} \mathrm{C}\right)$ & 17.92 & 12.30 & 22.0 & 23.0 \\
Relative humidity $(\%)$ & 45.36 & 57.35 & 73.0 & 84.0 \\
Total rainfall $(\mathrm{mm})$ & 3.41 & 2.0 & 85.0 & 101.0 \\
Rainy days & 10 & 2 & 15 & 18 \\
\hline
\end{tabular}

Table 2. DNA damage of erythrocytes of $O$. niloticus $(\mathrm{n}=5)$ exposed to the waters of the Paraíba do Sul river.

\begin{tabular}{|c|c|c|c|c|c|}
\hline \multirow{2}{*}{ Collection } & \multicolumn{4}{|c|}{ Proportion of damaged nucleiods $(\%)^{\mathrm{a}}$} & \multirow[t]{2}{*}{ Average damage score } \\
\hline & 0 & 1 & 2 & 3 & \\
\hline \multicolumn{6}{|l|}{ May 2004} \\
\hline Control & 86.6 & 9.2 & 3.6 & 0.6 & $18.2 \pm 9.0$ \\
\hline Point 1 & 82.0 & 10.3 & 6.0 & 1.8 & $27.6 \pm 10.0$ \\
\hline Point 2 & 6.6 & 13.0 & 32.3 & 48.4 & $222.2 \pm 25.6^{*}$ \\
\hline Point 3 & 6.6 & 12.4 & 21.8 & 59.2 & $229.4 \pm 31.9 *$ \\
\hline \multicolumn{6}{|c|}{ August 2004} \\
\hline Control & 80.2 & 9.4 & 5.0 & 5.4 & $35.6 \pm 21.4$ \\
\hline Point 1 & 40.8 & 27.2 & 19.2 & 12.8 & $104.0 \pm 24.5^{*}$ \\
\hline Point 2 & 7.6 & 14.8 & 35.4 & 42.2 & $212.2 \pm 40.5^{*}$ \\
\hline Point 3 & 14.2 & 12.4 & 29.0 & 44.4 & $203.6 \pm 35.6^{*}$ \\
\hline \multicolumn{6}{|c|}{ November 2004} \\
\hline Control & 72.4 & 10.4 & 10.6 & 6.6 & $30.2 \pm 10.6$ \\
\hline Point1 & 58.2 & 16.6 & 17.0 & 8.2 & $71.2 \pm 18.7$ \\
\hline Point 2 & 6.4 & 19.0 & 43.4 & 31.2 & $205.4 \pm 24.5^{*}$ \\
\hline Point 3 & 12.8 & 16.2 & 30.0 & 41.0 & $199.2 \pm 43.8^{*}$ \\
\hline \multicolumn{6}{|c|}{ January 2005} \\
\hline Control & 79.2 & 13.0 & 6.2 & 1.6 & $29.0 \pm 23.7$ \\
\hline Point 1 & 71.8 & 18.9 & 7.0 & 2.4 & $40.0 \pm 18.4$ \\
\hline Point 2 & 3.2 & 29.0 & 26.0 & 41.8 & $196.6 \pm 37.2 *$ \\
\hline Point 3 & 9.4 & 19.2 & 33.8 & 37.6 & $199.6 \pm 36.2 *$ \\
\hline
\end{tabular}

Point 1: amount of disposal of effluent from oil refinery, point 2: dump site of the effluent from oil refinery, point 3: downstream of the discharge of the effluent from oil refinery

$* \mathrm{p}<0.01$ when compared with control group.

${ }^{a}$ Categories of the migration of comets: 0 - 3 (Rigonato et al., 2005)

Average damage score: average \pm standard deviation

\section{DISCUSSION}

Several factors can affect the degree of pollution in a river, such as hydrological and climatic conditions. Seasonal variations of these factors have a great effect on the concentration of pollutants in the aquatic environment (Vega et al., 1998).

It is likely that the compounds detected in the upstream part of the Paraíba do Sul River come from other pollution sources located upstream from point 2 (dumping of the effluent from an oil refinery). In August, rainfall was low in the region studied, and therefore the volume of river water tended to decrease. This factor may have contributed to a greater concentration of pollutants upstream, unlike that seen in the other months studied.

The São Paulo region of the Paraiba do Sul River is heavily industrialized and urban. We cannot guarantee that the DNA damage observed was a result of the refinery effluent only, since no chemical analyses were carried out. However, several researchers have reported the harmful effects of refinery effluents (Çavas \& Könen, 2005; Hoshina et al., 2008 and 2009) and these effluents may have contributed to affecting the water quality of the Paraíba do Sul River.

This hypothesis is supported by the presence of genotoxins in the areas of the Paraíba do Sul River influenced by the oil industry. The same sampling points were analyzed previously by Souza \& Fontanetti (2006), through the micronucleus (MN) test in erythrocytes of $O$. niloticus, showing that genotoxins detected in the Paraíba do Sul may also have mutagenic potential for the fish species studied.

Çavas \& Könen (2005) and Hoshina et al. (2008) found that the final effluent from the oil refineries induced high frequencies of micronuclei and nuclear abnormalities in the gills and erythrocytes of $O$. niloticus, showing the harmful 
effects of waste from the petrochemical industry on the genetic material of aquatic organisms.

Pantaleão et al. (2006) monitored the Japaratuba River using the MN test in two fish species: Hoplias malabaricus and Astyanax bimaculatus. This river receives the wastewater from a petrochemical complex. Water is taken from the river, used in the production of oil and gas, separated from these compounds, and then discharged back into the river. The main contaminants of the water are: mono and polycyclic aromatic hydrocarbons, alkylphenols, and metals (arsenic, barium, cadmium, iron, manganese, lead, zinc and mercury). Significant frequencies of MN were observed only in erythrocytes of $A$. bimaculatus from two sampling sites.

The effect of a petrochemical complex in rivers of Rio Grande do Sul State has been evaluated for different species of fish (Lemos et al., 2007 and 2008). The cytotoxicity and mutagenicity of the Bom Jardim Brook was demonstrated with the MN test and the presence of nuclear abnormalities in Astyanax jacuhiensis, a native species of the region. Organisms collected in front of the area where the final effluent is deposited on the river had the highest MN frequencies, compared with the other sites examined. The low quality of the Bom Jardim Brook was attributed to the high levels of chlorides, total solids, and conductivity found in the water (Lemos et al., 2008).

Also, Odeigah et al. (1997) and Hoshina \& Marin-Morales (2009) reported the induction of chromosome aberrations and micronucleus in $A$. cepa, demonstrating that other organisms can be affected by effluents from petroleum refinery.

The water of several rivers analyzed in these studies is used for human consumption, irrigation, and recreation, after conventional treatment according to state laws (Souza \& Fontanetti, 2006; Lemos et al., 2007; Hoshina et al., 2008). However, these studies have shown that although the residues of petrochemical plants are treated and the contaminants removed and reused within the plant, the final effluent discharged into the aquatic environment may still contain large amounts of genotoxic and mutagenic compounds.

This study found primary damage in the DNA of $O$. niloticus erythrocytes after exposure to waters that receive effluent from an oil refinery. The continuance of biological studies for the detection of genotoxicity is of extreme importance for monitoring rivers that receive effluents from polluting industries.

\section{ACKNOWLEDGMENTS}

We thank Prof. Dr. Dejanira Francheschi de Angelis from the Water Toxicity Laboratory - Department of Biochemistry and Microbiology, UNESP, Rio Claro, Valdenilson José Alves de Oliveira and Marcelo Sousa Camargo for the collection of water samples, Prof. Dr. Eliana Gonçalvez, UNESP, São Jose do Rio Preto, for providing us with the samples of Oreochromis niloticus, the Department of Air Space Control São Paulo Flight Protection Service for providing us with the climatological data in São José dos Campos and the Human Resources Program from ANP/FINEP/MCT-CTPETRO, PRH-05, Universidade Estadual Paulista - UNESP, Rio Claro, São Paulo and the Foundation for the Development of UNESP (FUNDUNESP) for the financial support.

\section{REFERENCES}

BIAGINI, F.R., DAVID, J.A.O. \& FONTANETTI, C.S., 2009. The use of histological, histochemical and ultramorphological techniques to detect gill alterations in Oreochromis niloticus reared in treated polluted waters. Micron, 40: 839-844. doi: 10.1016/j.micron.2009.10.009

BRAILE, K.W. \& CAVALCANTI, J.E.W.A. 1993. Tratamento de águas residuárias industriais. São Paulo: CETESB, 764p.

ÇAVAS, T. \& ERGENE-GOZUKARA, S., 2005. Induction of micronuclei and nuclear abnormalities in Oreochromis niloticus following exposure to petroleum refinery and chromium processing plant effluents. Aquat. Toxicol., 74: 264-271. doi: 10.1016/j.aquatox.2005.06.001

ÇAVAS, T. \& KÖNEN, S., 2008. In vivo genotoxicity testing of the amnesic shellfish poison (domoic acid) in piscine erythrocytes using the micronucleus test and the comet assay. Aquat. Toxicol., 90: 154-159. doi: 10.1016/j.aquatox.2008.08.011

CHRISTOFOLETTI, C.A., DAVID, J.A.O. \& FONTANETTI, C.S., 2009. Application of the comet assay in erythrocytes of Oreochromis niloticus (Pisces): A methodological comparison. Genet. Mol. Biol., 32: 155-158. doi: 10.1590/S141547572009005000020

Companhia de Tecnologia e Saneamento Ambiental (CETESB), 1987. Guia de coleta e preservação de amostras de água. Coord. Edmundo Garcia Agudo (et al.), São Paulo.

Conselho Nacional do Meio Ambiente (CONAMA), 2005. Resolução 357 de 15 de marco de 2005, Brasilia, Distrito Federal, available in www.mma.gov.br (accessed on: April 15, 2008).

Convênio PETROBRÁS-FUNDUNESP, 2003. São José dos Campos. Relatório.

GRISOLIA, C.K. \& CORDEIRO, C.M.T., 2000. Variability in micronucleus induction with different mutagens applied to several species of fish. Genet. Mol. Biol., 23: 235-239. doi: 10.1590/S1415-47572000000100041

HOSHINA, M.M., ANGELIS, D.F. \& MARIN-MORALES, M.A., 2008. Induction of micronucleus and nuclear alterations in fish (Oreochromis niloticus) by a petroleum refinery effluent. Mutat. Res., 656: 44-48. doi: 10.1016/j.mrgentox.2008.07.004

HOSHINA, M.M. \& MARIN-MORALES, M.A. 2009. Micronucleus and chromosome aberrations induced in onion (Allium cepa) by a petroleum refinery effluent and by river water that receives this effluent. Ecotoxicol Environ Saf., 72: 2090-2095. doi:10.1016/j. ecoenv.2009.07.002

LEMOS, C.T., RÖDEL, P.M., TERRA, N.R., OLIVEIRA, N.C.A. \& ERDTMANN, B. 2007. River water genotoxicity evaluation using micronucleus assay in fish erythrocytes. Ecotoxicol. Environ. Saf., 66:391-401. doi: 10.1016/j.ecoenv.2006.01.004

LEMOS, C.T., IRANÇO, F.A., OLIVEIRA, N.C.A. SOUZA, G.D. \& FACHEL, J.M.G. 2008. Biomonitoring of genotoxicity using micronuclei assay in native population of Astyanax jacuhiensis (Characiformes: Characidae) at sites under petrochemical influence. Sci Tot Environ., 406:337-343. doi: 10.1016/j. scitoteenv.2008.07.006

ODEIGAH, P.G.C., NURUDEEN, O. \& AMUND, O.O., 1997. Genotoxicity of oil field wastewater in Nigeria. Hereditas, 126:161-167. doi: 10.1111/j.1601-5223.1997.00161.x 
PALHARES, D. \& GRISOLIA, C.K., 2002. Comparison between the micronucleus frequencies of kidney and gill erythrocytes in tilapia fish, following mitomycin C treatment, Genet. Mol. Biol., 25:281-284. doi: 10.1590/S1415-47572002000300005

PANTALEÃO, S.M., ALCÂNTARA, A.V., ALVES, J.P.H. \& SPANÓ, M.A. 2006. The piscine micronucleus test to assess the impact of pollution on the Japaratuba River in Brazil. Environ. Mol. Mut., 47:219-224. . doi: 10.1002/em.20188

RIGONATO, J., MANTOVANI, M.S. \& JORDÃO, B.Q., 2005. Comet assay comparison of different Corbicula fluminea (Mollusca) tissues for the detection of genotoxicity. Genet Mol Biol, 28:464-468. . doi: 10.1590/S1415-475720050003000023

RUSSO, C., ROCCO, L., MORESCALCHI, M.A. \& STINGO, V., 2004. Assessment of environmental stress by the micronucleus test and comet assay on the genome of teleost populations from two natural environments. Ecotox. Environ. Safe., 57:168-174. doi: 10.1016/S0147-6513(03)00027-7

SINGH, N.P., McCOY. M.T., TICE, R.R. \& CCHEEIDER, E.L., 1988. A simple technique for quantification of low levels of DNA damage in individual cells. Exp. Cell Res., 1:184-191. doi: 10.1016/0014-4827(88)90265-0
SOUZA, T.S \& FONTANETTI, C.S., 2006. Micronuleus test and observation of nuclear alterations in erythrocytes of Nile tilapia exposed to waters affected by refinery effluent. Mutat. Res., 605: 87-93. doi: 10.1016/j.mrgentox.2006.02.010

TAVARES-DIAS, M. \& MORAES, F.R., 2003. Características hematológicas da Tilapia rendalli Boulenger, 1896 (Osteichthyes: Cichlidae) capturada em "pesque-pague" de Franca, São Paulo, Brasil. Biosci. J., 19:103-110.

TICE, R.R., 1995. The single cell gel/ comet assay: a microgel electrophoretic technique for the detection of DNA damage and repair in individual cells, pp. 315-339. In: Phillips, D.H.; Venitt, S. (Eds.), Environmental Mutagenesis. Bios Scientific Publishers, Oxford.

VEGA, M., PARDO, R., BARRADO, E. \& DEBÁN, L., 1998. Assessment of seasonal and polluting effects on the quality of river water by exploratory data analysis. Water Res., 32: 35813592. doi: 10.1016/S0043-1354(98)00138-9

VENTURA, B.C., ANGELIS, D.F. \& MARIN-MORALES, M.A., 2008. Mutagenic and genotoxic effects of the Atrazine herbicide in Oreochromis niloticus (Perciformes, Cichlidae) detected by the micronuclei test and the comet assay. Pestic. Biochem. Physiol., 90: 42-51. doi: 10.1016/j.pestbp.2007.07.009 